\title{
Do relato do discurso ao discurso polifônico em Eu Hei-de Amar uma Pedra
}

\section{Olívia Maria Figueiredo*}

\section{Resumo:}

O romance Eu Hei-de Amar uma Pedra é um romance característico dentro da obra de Lobo Antunes. É uma obra onde não há uma linha romanesca como nos romances tradicionais. O romance divide-se em quatro partes (as fotografias; as consultas; as visitas; as narrativas) aparentemente sem sentido entre si. Mas o filamento condutor que liga as partes são as vozes das personagens que ao longo da obra se ouvem em recordações de momentos da sua vida. O jogo polifónico das várias vozes repetidas até à exaustão mantém as personagens vivas através de força ilocutória da enunciação. A subjectividade transforma-se, assim, em intersubjectividade e em espelho de actos psicológicos que se expressam por meio de unidades soltas deixando ao leitor o cumprimento de as encaixar umas nas outras. Assim, as personagens vão tomando corpo e alma ao longo da obra por meio de evocações em eco de cada acto de fala que, embora proposicionalmente idênticos, se tornam intencionalmente diferentes por cada repetição. Dizer é fazer, mas falar é também construir-se. A análise dos actos de fala esclarece eficazmente o funcionamento do diálogo romanesco nas obras de António Lobo Antunes. O mesmo acontece neste romance.

\section{Palavras-chave:}

Discurso relatado; actos de fala; polifonia

Visão e voz visceral da Vida, [...] a ficção do autor [...] é, por excelência, um eco ampliado, complexo, subtil e atroz do que há de insólito e imprevisível nessa vida. Eduardo Lourenço, A Morte do Pai

O surpreendente na obra antuniana, desde as suas crónicas aos romances mais actuais, é a permanência dos enunciados ecóicos que atravessam todos os textos. A instanciação de um movimento discursivo manifestamente monofónico, diafónico e polifónico materializa-se nas várias vozes em eco (Figueiredo, 2004a, p. 324) que convertem o facto mais usual e menos poético da vida em literatura. Processo retroactivo para assegurar a coesão semântica do discurso narrativo em sequência (Figueiredo, 2004b, p. 231), as retomas em eco permitem a recapitulação na reformulação de pontos de vista e a reflexão na mudança da perspectiva enunciativa, relativamente ao movimento discursivo anterior. 
Ainda e sempre, também em Eu Hei-de Amar Uma Pedra os enunciados ecóicos constituem o processo-chave da construção textual da narrativa antuniana. O romance divide-se aparentemente em quatro partes (as fotografias, as consultas, as visitas, as narrativas) sendo que cada parte se divide, por sua vez, em capítulos, (cada capítulo, ou uma fotografia, ou uma consulta, ou uma visita, ou uma narrativa) numa estruturação em crescendo até ao clímax final. Aparentemente desconexas e desconexos entre si, partes e capítulos revelam-se, no entanto, deveras coerentes na recolha da vasta memória dos fragmentos que se vão espelhando de parte a parte, de capítulo a capítulo, de página a página. Esta odisseia do "mar sempre recomeçado", no dizer de Eduardo Lourenço, corresponde à "visão e voz visceral da Vida, menos como natureza com as suas leis mais ou menos fatais do que como realidade humana" (Lourenço, 2004). E como a vida não tem leis, também sem leis o livro "começa a formar-se sozinho, filamentos vagos que se aproximam, substantivos casuais flutuando ao acaso por aqui e por ali, cheiros, vultos ora sombra ora luz, coisas sem importância que aumentam e afinal não coisas, o que escutei, o que vivi, o que adivinho" (Lobo Antunes, 2002).

Eu Hei-de Amar Uma Pedra é um livro que, como os demais de Lobo Antunes, tem como filamento condutor o interdiscurso de vozes enunciadas em indistintos / distintos chamamentos de silêncios. São vozes de personagens que ao longo da obra se ouvem em ressonâncias profundas, à semelhança da ninfa Eco que, perdido o corpo por amor, recupera a existência por meio da sonoridade, a voz da quintaessência ("Vox manet...sonus est, qui vivit in illa" - Ovídio, Metamorfoses III).

A obra abre com a primeira fotografia: "Tenho dois anos e estou ao colo da minha mãe" (Lobo Antunes, 2004, p. 15).

Está lançado o tom. Esta personagem central da narrativa com voz e sem nome na narrativa, "um único vidro sujo no qual nenhum mindinho escreveria o seu nome, num segundo andar do Jardim Constantino" (Idem, p. 34), e porque "as gaivotas comiam letra a letra o meu nome, esta consoante, esse arabesco de vogal" (p. 57), depara-se com a imagem dos "parentes da camilha em cercaduras ovais [...] a decidirem por mim" (p. 21, 22).

A sua existência identificadora não se rege pois, por um nome de baptismo, por um nome de família, mas pelas designações que Ihe são atribuídas ao longo da sua vida e que lhe advêm das suas circunstâncias. Diante do retrato, do tempo em que o que melhor conhecia da sua mãe eram os pés "(nessa época conheciaIhe melhor os pés do que a cara)" (p. 24), o que recorda são as vozes de chamamento de antanho que, em catadupa, se amplificam em círculos concêntricos desde os dois anos de idade, época da primeira fotografia:

É o [...] eco antigo no qual parentes muito idosos estremeciam - Pimpolho (p. 17).

É a voz do empregado roído pelos ácidos, o senhor Querubim

- Aguente o pimpolho madame que Ihe escorrega do colo ( $p .18$ )

é a voz do primo Casimiro

- Está a rir-te de quê? (p. 18)

- Um dia destes volto pimpolho (p. 27) 
- Juro que um dia destes volto pimpolho (p. 27)

é a voz do pai (que partiu há dez anos no comboio de emigrantes de Paris)

- Trambolhos (p. 18)

é a voz da madrinha da mãe

- O pimpolho cresceu tanto este ano (p. 21)

Ao longo de toda a parte referente às "fotografias", que são dez, há toda uma galeria de fotografias amarelecidas, onde se descortinam retratos distorcidos pelo tempo e de onde encantatoriamente sobressaem as mesmas vozes numa epifania crescente de intencionalidades catastroficamente obsessivas até ao ponto de ainda ouvirmos a voz do "senhor Querubim de mãos roídas dos ácidos" enunciar, na altura em que trazia "os guaches [...], a corrigir as bochechas a cor-de-rosa, a ajardinar-Ihe a calvície":

- Dás ares do teu pai pimpolho

não sem espanto do pimpolho

- Dou mesmo ares do meu pai a sério?

como se um chapéu e um cigarro, como se duas canas de pesca, uma palma a evitá-lo

- Trambolho (p. 144)

A nona fotografia, da praia de Tavira, "foi a minha filha mais velha que tirou" (Ibid., p. 199) e a décima "é a fotografia num restaurante da Baixa dos anos de casados dos meus pais" (Ibid., p. 225), relata a filha mais velha. A partir daqui, vai ser esta a filha que, por sua vez, vai dar conta do fadário fantasmagórico que cada fotografia revela e a dar conta disso e, de quando em vez, também surgindo à boca da cena para rememorar "a minha irmã sem ocupar o banco da capela junto à minha mãe e a mim, encostada à parede de mãos sumidas no casaco com o lábio nos dentes e nisto, sem motivo algum, veio-me à lembrança o postal do álbum de fotografias com as acácias de Sintra" (p. 245),

[...] nós os dois no Beato compreendes e talvez um comboio de França, o meu pai a acender um cigarro no pontão

- Trambolho

e apesar do

- Trambolho

eu bem disposto, a enfermeira a forçar-me a olhá-la

- Estás doente? (p. 316)

Agora a parte dois: as consultas, que são cinco. Aqui, o quadro frisado de memórias vai sendo dedilhado pela mulher que vem sempre acompanhada do seu "saquito de crochet", uma doente de 82 anos, sexo feminino, "idade aparente coincidindo com a real" que se revela ao psiquiatra sentado "na cadeira de braços deste lado da secretária" e "a doente a escutar-me na cadeira [...] conforme na última tarde na hospedaria da Graça" [...] (p. 308) 
[...] e a doente a escutar o Beato, quer dizer não as casas

(tão poucas as casas meu Deus, hoje prédios no sítio onde hortas, quintinhas, restos de pombais desertos)

não a igreja, o Tejo, um desconhecido no extremo do pontão recusando um miúdo com o desprezo da manga

- Trambolho

o fotógrafo que assomou de uma cave a hesitar

- pimpolho? (p. 309)

Já na parte correspondente "às visitas", que tem início na p. 365, a primeira visita começa com a voz da filha da madrinha da mãe do pimpolho, "uma prima secundária em que ninguém reparava" (p. 545): "Não sei há quanto tempo o pimpolho me mandou embora do segundo andar do Jardim Constantino" (p. 365).

Nesta parte, constituída por três visitas, é ainda "o pimpolho" a isotopia que estabelece o cordão umbilical da narrativa através da presentificação das vozes em eco

porque não era este segundo andar do Jardim Constantino que ele queria, era um comboio voltando de França, um gesto que fosse a enxotá-lo

- Trambolho

E o pimpolho que você diz ser seu pai contente, sossegado [...] (p. 375)

que duram e perduram

[...] e o pimpolho na estação continuando connosco, acertámos que espiolhasse as carruagens, sem tempo para nós. Mesmo na hospedaria da Graça ou Tavira ou em Sintra, receando que o pai dele

- Trambolho

Conforme você sem palavras nos almoços de domingo

- Trambolho (p. 390)

[...] a linhazinha do horizonte com um paquete ou isso, no paquete o primo Casimiro

- Estás a rir-te de quê? (p. 395)

(para quê um comboio?)

e recusando-o de novo consoante o recusava em criança

- Trambolho (p. 421).

[...] um primo idoso com um pacotinho de broas que me fazia cócegas

- Estás a rir-te de quê? (p. 422)

A quarta e última parte é constituída por sete capítulos, com narradores distintos. São histórias ligadas ao "eu de chapéu de palha com cerejas de feltro" (p. 472), 
ao senhor das quartas-feiras na hospedaria da Graça, o senhor que morava com a esposa e as filhas no Jardim Constantino, "o senhor que herdei da minha mãe nas escadas, a senhora à espera no 12 [...], o senhor que em tantas quartas-feiras e no caso de não haver mentido [...] fui conhecendo aos poucos, morava no Jardim Constantino" (p. 476) com a esposa, duas filhas, o genro, a filha sem genro; são perguntas angustiadas da filha mais velha do "pimpolho" "(Tinha de ser assim não era pai?)" (p. 487), "de fazer os possíveis por me envergonhar até ao último dia", "tinha logo de morrer de propósito numa dessas espeluncas baratas que deviam proibir quartos à hora [...]". Relembrando ainda que, de todas as vezes que a palavra "trambolho" era pronunciada, o pai estremecia como se revivesse a sua própria voz quando no antanho se Ihe dirigiam

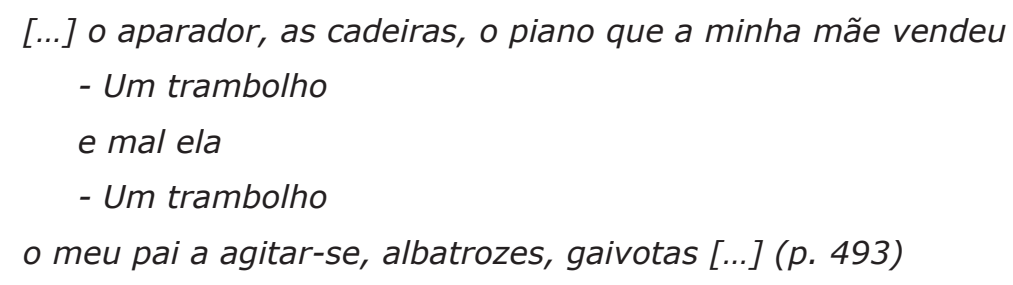

A quarta narrativa começa com a voz da mulher do pimpolho, "O meu marido faleceu há dois meses...numa dessas quartas-feiras em que saía contra minha vontade" (p. 511).

Também esta personagem traz à presença memórias fantasmagóricas. Não só a do marid, "[...] o meu marido [...] não se preocupa [...] não se alarma comigo, circula entre fantasmas habituado a eles" (p. 513), como a de outras pessoas que com ela, em algum momento da sua vida, privaram:

[...] a conviç̧ão que pessoas que não conheço instaladas no sofá reprovando-me, por muito que argumentem que a saleta vazia uma velhota embrulhada em xailes e mantas a admirar-se para uma rapariga de pé

- Cresceu tanto este ano o pimpolho

um sujeito que erguia um catraio no ar, Ihe fazia cócegas, o largava no soalho a indignar-se com as mãos na cintura

- Estás a rir-te de quê?

uma mulher de chapéu de palha com cerejas de feltro protestando comigo

- Deste-me tanto trabalho (p. 513)

Por outro lado ainda, a presença dos retratos na camilha como um anátema do passado a marcar as angústias do presente:

- Não saia de casa

como se uma senhora decente saísse de casa às seis e onze da tarde num andar em que os retratos me vigiam

- Quem é que pensas que és?

eu no banquito da marquise, onde as criaturas da camilha não podiam espiar-me [...] 
(p. 520)

Na quinta narrativa recupera-se o fantasma da "criatura do chapéu de palha, [...] a fotografia dela na camilha do Jardim Constantino mas qual, a velhota de bengala, a rapariga das tranças, uma prima secundária em que ninguém reparava" (p. 545). E volta, em rodopio acelerado, as vozes marteladas que ecoam desde o início do romance:

[...] um indivíduo de mãos roídas pelos ácidos

- Pimpolho

outro a largá-lo no sobrado

- Estás a rir-te de quê?

um navio

(ou uma nuvem)

a afastar-se devagar para a América [...] o indivíduo que o largou no sobrado a acenar do navio

(da nuvem?)

a acenar à sua mãe do navio

- Um dia volto pimpolho (p. 553)

\section{[...] o teu pai [...] as canas de pesca que o enxotavam}

- Trambolho (p. 553, 554)

[...] a vizinha do toldo

(outro monstro)

no seu crochet o dia inteiro, alheada de vocês, ano após ano a mesma cadeira de lona, o mesmo vestido, um cumprimento de cabeça que mal se notava, cerimonioso, a custo (p. 556)

Na penúltima narrativa ouve-se o lamento da filha mais velha, "a gente a supor que as coisas terminam e aí estão elas vivas, os meus pais vivos mesmo que duas pedras com datas e letras" (p. 571). A "última narrativa" é o fecho do livro por "uma criatura de chapéu de palha com cerejas de feltro" (p. 616).

Toda a obra é uma metáfora "tilintando recordações no bolso da memória" como se diz lá para a página 298. As vozes, imperiosos gritos de ausências presentes, ecoam naquela caverna do segundo andar do Jardim Constantino, naquela saleta e naquela camilha, naqueles retratos que marcam os episódios mais fortemente vividos por todas aquelas personagens sem nome, reconhecíveis apenas pelos seus encontros / desencontros, pelas suas relações familiares, pelos seus restos de vidas espalhados pelos mesmos espaços e, sobretudo reconhecíveis pelas vozes que consigo trazem e que consigo arrastam.

Vivamente, as vozes conservam e manifestam, em profundas ressonâncias, os vários momentos da vida de cada personagem. E bastam "certas coisas, nunca as que supomos mais interessantes, nunca aquelas que nos comoveram, permanecem intactas" (p. 594). E bastam as vozes para aí caber o mundo todo. E o coro 
das vozes, em sucessivos redemoinhos, faz vibrar em infinitas reminiscências parcialidades / totalidades vividas em permanente retorno. Entendido aqui o eterno retorno como uma necessidade circular de cada ser que, para existir, tem de exprimir-se através do ritmo disseminado de simulacros, cópias de uma infinidade de cópias, num processo pelo qual o espaço se torna tempo e o tempo espaço. A polifonia, noção trazida pelas teorias de enunciação, interroga-se sobre a heterogeneidade e a hierarquização das vozes discursivas no interior de um mesmo texto. Em Eu Hei-de Amar uma Pedra, esse jogo entre as várias vozes, repetidas até à exaustão, traduz as enunciações locutoriamente postas em cena pelas personagens que são forçadas a isso para continuarem a manter-se vivas, se não sempre, pelo menos até ao momento em que "uma criatura de chapéu de palha com cerejas de feltro [...] empurre a porta de súbito sem respeito por nós e nos expulse para a rua [...] a informar mudei de plano, não preciso de vocês, sou eu que fecho o livro, vão-se embora, acabou-se." (p. 616).

Em Lobo Antunes, depara-se o leitor com um concerto de vozes distintas. Ou são as falas das personagens que, em estrutura diafónica, se respondem em intervenções de troca,

[...] a minha mãe a desviar a vista quando chamei por ela

- Mãe

a evitar responder

- Estou aqui

a não querer responder

- Estou aqui

e em lugar de

- Estou aqui

a censurar-me

- Por quê?

eu que não era o meu pai mãe, não a abandonei, ajudei-a a procurá-lo no beco [...] (p 97)

ou são vozes que o(s) narrador(es) evoca $(m)$ a título de objecto de referência recuperando-as polifonicamente por meio de formas mais ou menos canónicas de transcrição.

Discurso directo, introduzido pelo travessão e nunca por dois pontos,

- Estás a rir-te de quê?

o empregado a espanejar o castelo, desconfiado de mim

- Estás a rir-te de quê se ainda não comecei? (p. 26)

\section{[...] nisto uma voz a amedrontá-lo}

- Está a rir-te de quê?

um vulto tão pálido como os Sempre Queridos, fugido da camilha a secar promessas no bigode 


\section{GกIInBUT GBIIIÓกE}

- Um dia destes volto pimpolho (p. 180)

algumas vezes, com introdução do verbo de relato de discurso (sublinhados meus),

a minha filha mais nova a desculpar-se

- Ai a idade dele mãe) (p. 123)

\section{[...] e eu a avisar-te calado}

[...]

- Se julgas que eu caso contigo tira daí o sentido (p. 147)

[...] dava a sensação de desconfiar de mim pronto a ameaçar-me, a expulsar-me

- Fixe a cruzinha e não pisque os olhos Madame (p. 152)

[...] não se transtorne comigo, não me olhe e eu a pedir sem dizê-lo

- Não desapareças de mim

com vontade de gritar e incapaz de gritar ou a gritar

- Acaba de abrir e fechar a mala que gaita (p. 162)

[...] um vulto pálido [...] fugido da camilha a secar promessas no bigode

- Um dia destes volto pimpolho [p. 180)

mas você um pulha como nós pai, você um pulha paizinho, por sua causa o meu irmão de Herodes para Pilatos a pedinchar, a jurar

(o que lhe deve ter custado, percebe?)

- Para o ano que vem no máximo satisfaço essa dívida ( $p$. 589)

Os verbos introdutores de relato de discurso destes exemplos (desculpar-se, avisar, ameaçar, pedir, secar promessas, jurar) confirmam que as falas que eles introduzem executam uma acção, bastando somente o facto de serem alvo de uma enunciação. Estes enunciados com carácter performativo (dizer é fazer) realizam os actos que eles denominam, pelo facto de se encontrarem na primeira pessoa e no presente do indicativo. A relação entre actos de fala performativos ("- Vai-me desculpar não vai?" (p. 162)) e actos de fala constativos ("sabendo que não iria desculpar-te ou tendo receio que não te desculpasse", p. 162) constitui os alicerces materiais ("uns quantos tijolos de palavras") (LOBO ANTUNES, 2008) onde se sustenta a arquitectura da obra.

Em outros casos, a maioria, as falas não são introduzidas por verbos de relato de discurso. Ainda assim, o seu carácter performativo não se dilui,

[...] o primo Casimiro emigrou para a América e chovia, julguei que lágrimas e não lágrimas, chuva no bigode, o perfume de verbena de loção

- Um dia destes volto Pimpolho 
comigo a pensar volte se Ihe der na gana [...] (p. 27)

as palmeira da Guiné ao vento e nós cabras que mancavam, nós balindo, se o primo Casimiro comigo

- Está a rir-te de quê?

ele que nunca ria nunca a pedir esmola à minha mãe com os olhos (p. 63)

a minha mãe que apanha os sentimentos na atmosfera, ela sim a cadela, não eu

- Tens alguma coisa contra o teu pai tu?

não tenho nada, faleceu, por mim junte os defuntos todos senhora, os seus pais, os seus cunhados, a tropa fandanga que você colecciona (p. 331).

Neste caso, estando o verbo relator implícito, é a força ilocutória da enunciação que traz a marca do performativo (de promessa - Um dia destes volto pimpolho; de censura - Está a rir-te de quê?; de ameaça - Tens alguma coisa contra o teu pai?).

Estas características levam a considerar que, neste romance, a subjectividade tem de ser vista em termos de intersubjectividade uma vez que a linguagem tem de ser considerada não só como meio de acção das personagens consigo próprias, mas também de interacção das personagens entre si num misto de um processamento de influências mútuas: falar é actuar e interage-se falando.

De acordo com Austin (1962), dizer é fazer, no sentido em que um acto de fala executa uma acção só pelo facto da sua enunciação. Em Eu Hei-de Amar Uma Pedra, os actos de fala jamais são espelhos de verdades factuais; são quase sempre agressões, promessas, ajustes de contas, ameaças, rememorações, dúvidas que se inscrevem nos enunciados implicados na intersubjectividade linguística. Intersubjectividade acrescida pelo facto de parte dos actos de fala exprimirem fórmulas indirectas, o que reforça a expressão do estado psicológico a respeito do que especificamente se expressa no conteúdo proposicional do enunciado. Ao exprimir-se indirectamente, o enunciador parece informar de um facto, mas o que pretende é suscitar sempre uma conduta.

Os actos de fala indirectos são enunciados que orientam superficialmente para um determinado significado mas que profundamente exprimem um valor ilocutório diversificado:

[...] quase a zangar-me (a zangar-me)

- Proíbo-vos de chorar entenderam? (p. 168)

\section{[...] a reprovar-me sem ralhos}

(era o que faltava ralhos)

de labiozinho franzido

- Que tal o meu penteado senhora ? (p. 183) 
corpo obediente, as patas que vacilam

- Disse não te mexas não disse? (p. 356)

Nos três casos, a forma do enunciado é uma pergunta, mas os valores ilocutórios são diferentes: ilocutoriamente, o primeiro enunciado é uma ameaça; o segundo é um pedido de opinião; o terceiro é uma ordem. Para a correcta descodificação do valor ilocutório dos enunciados, sejam eles actos de fala directos ou indirectos, é essencial o contexto que joga aqui um papel decisivo na hierarquia dos valores literal e derivado. No geral, quanto mais um valor ilocutório é fortemente codificado em língua, menos ele tem necessidade do contexto para se actualizar; e inversamente: quanto menos um valor é "convencional" mais a sua actualização é tributária do contexto de enunciação. No caso do texto literário e deste romance em particular, embora os actos de fala estejam na língua já codificados, o contexto intervém forte nos valores convencionais, levando o leitor, por uma espécie de derivação ilocutória, a reinterpretar o acto de fala de acordo com a personagem no momento em que o enuncia, de acordo com o enunciatário e de acordo com a insistência da sua reprodução nas várias enunciações ao longo da obra. De cada vez que são retomadas, renascem das cinzas e novas virtualidades de encadeamentos sequenciais são criadas, o que permite à organização discursiva balizar-se entre dois movimentos: retroactivo e proactivo. Sem estrutura dialogal à vista e sem uma linha narrativa cronológica clássica, a arquitectura complexa do romance fabrica-se a partir de unidades aparentemente soltas que deixa ao leitor o cumprimento de as encaixar umas nas outras.

A produção em eco dos actos de fala, que não cessam de evoluir em crescendo no decorrer da narrativa, são um meio privilegiado para se encontrar a relação dialéctica entre o contexto e o texto, ou seja entre o quadro e os actos de fala produzidos nesse quadro.

A construção do mundo referencial no romance, partindo do princípio que os objectos imaginários da ficção têm um referente, é reduzida ao mínimo. Quase não há ancoragens objectivas por meio de nomes próprios, nem ancoragens cronológicas temporais: são pouquíssimas as personagens com nome próprio (o primo Casimiro, o senhor Querubim, a Raquel); não se indicam cronologicamente datas, nem dias, nem meses, apenas eventos temporais, normalmente relacionados com anos de idade; ("Tenho dois anos e estou ao colo da minha mãe", p.15; "ela que não morou senão nesta casa em sessenta ou setenta anos de Lisboa", p.31; "não acho que setenta anos, setenta anos em Julho", p. 126; "Doente de 82 anos [...], idade aparente coincidindo com a real", p. 252). A construção das personagens também não segue os cânones clássicos: a sua identificação na sequência textual é dada por designações como "o pimpolho", "o trambolho", "a minha mãe", "a madrinha da minha mãe", "a doente de 82 anos", "a criatura de chapéu de palha com cerejas de feltro". Mesmo as personagens que são denominadas com nomes próprios só têm existência própria por referência co(n)textual com as outras personagens. As instruções para identificar os referentes humanos são dadas, muitas vezes, através de grupos nominais definidos ("o pimpolho", "o 
trambolho"). Caberá ao leitor mobilizar características suplementares para isolar o referente visado por forma a que só um referente corresponda a tais propriedades. Só a relação com o contexto ficcional permitirá ao leitor aceder ao referente e identificá-lo como único.

Ao contrário do nome próprio que designa directamente o seu referente e o estabiliza numa comunidade de falantes, a designação indirecta, por meio de grupos nominais definidos, obriga o leitor a um trabalho de vigília de forma a recepcionar atitudes, comportamentos das personagens através dos seus dizeres e ditos. Assim, a personagem vai tomando corpo e alma ao longo da obra pelas evocações em eco de cada acto de fala que, embora proposicionalmente idêntico, se torna intencionalmente diferente por cada repetição. Dizer é fazer, mas falar é também construir-se.

A interpretação identificadora, denominativa e predicativa é uma característica do nome próprio. Nesta obra, as personagens que não têm nome vivem das vozes que as sustentam e lhe dão vida até ao final do romance. Chegadas as personagens aqui, assiste-se ao acabar das suas existências que só continuam enquanto ainda restar "uma palavra apenas à medida que os toldos e a ponte se desvanecem da memória", "enquanto a música se cala em pinguinhos de som" (p. 616). Neste quadro, onde as personagens também se identificam pelos lugares por onde deambularam, a ancoragem espacial segue sempre a mesma rota entre dois / três pontos de Lisboa, identificados pelo leitor: a "Photo Royal do Beato", o "segundo andar do Jardim Constantino", a "hospedaria da Graça", embora haja outros lugares como Sintra e Tavira também de forte importância para a compreensão das linhas narrativas da obra:

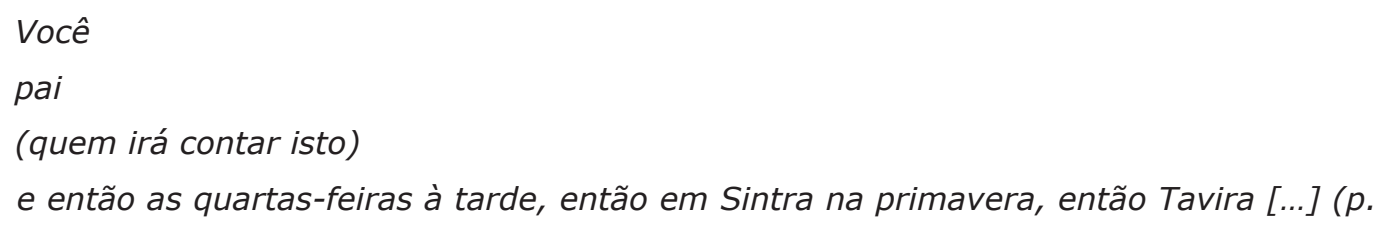

Uma vez identificados os objectos do romance (personagens e lugares), a coesão referencial é feita por anáforas discursivas que se realizam subjectivamente por meio de elementos pronominais ou adverbiais: eu/tu, agora, hoje, aqui: "- Tens alguma coisa contra o meu pai tu?"; "- Chega-me essa aí"; "- O que será isto?"; "- Nunca mais paro agora": "- Ainda agora nasceste e quase adulto meu Deus"; "- Não fazes a consulta hoje?"; "- Anda cá". Estes elementos linguísticos permitem mudar de referente em cada enunciação, o que não acontece com o nome próprio. O fundamental é que o leitor esteja disponível para identificar quem são os objectos eu/tu e os aqui/agora em cada situação implicada nos níveis de enunciação.

O discurso, neste teatro de representações, baliza-se alternadamente entre enunciações monofónicas, diafónicas e polifónicas (Bakhtine, 1984).

Nas primeiras ouve-se a voz de um só locutor: narrador ou personagem. Nas 
segundas o locutor interage em interlocução. Nas terceiras o locutor relata as palavras (ou os pensamentos) de outros locutores ou de si próprio.

Todo o enunciado é produto de um locutor primário que se responsabiliza por aquilo que enuncia e pelas enunciações suas ou de outros locutores que ele integra no seu próprio discurso. Neste processo, são várias as situações que representam as várias vozes em simultâneo uma vez que todo o discurso relatado constitui uma enunciação sobre uma outra enunciação.

Discurso directo. O locutor primário, aquele que enuncia o seu próprio enunciado e se responsabiliza por ele, pode ser ao mesmo tempo enunciador (locutor secundário) quando introduz no seu discurso um acto de fala seu produzido em outra altura que não no momento desta enunciação. O locutor primário e o locutor secundário têm o mesmo referente:

[...] depois eu para a filha da madrinha da minha mãe interrompendo-Ihe a costura no cubículo do fundo

- Dou-Ihe até ao fim do mês para sair de cá (p. 94)

O "eu" que profere "eu para a filha da minha madrinha" é o locutor primário; o "eu" de "- Dou-Ihe até ao fim do mês..." toma a forma de locutor secundário. O mesmo locutor integra uma sua enunciação do passado na sua enunciação do presente. Ambos os enunciados são de natureza discursiva. Este locutor primário pode estar explícito ("eu para a filha da madrinha") mas também pode estar implícito:

o casaco que parecia ao mesmo tempo faltar-lhe e sobejar-lhe, olhos que se escapavam, lábios perguntando ao tecto

- Tens a certeza que te dão de comer? (p. 118)

Este enunciado supõe um locutor primário implícito: [eu narrador, digo que] lábios perguntando ao tecto... Neste caso, a enunciação do primeiro nível "lábios perguntando..." é de natureza histórica (narrativa); a de segundo nível "- Tens a certeza que te dão de comer" é de natureza discursiva.

Este jogo entre discurso citante e discurso citado relaciona dois movimentos enunciativos que se dissociam nitidamente em duas situações de enunciação. O enunciador do discurso citante, quando faz recurso da fidelidade do discurso directo, dispõe de dois meios: marcar a fronteira do discurso citado por meio de um elemento tipográfico (travessão) ("- Não julguem que me comovo diante de ninguém", p. 320) e por meio (ou não) de um verbo cujo significado indica que há uma enunciação ("quis avisá-lo - Vais ficar sem mindinho e depois?", p. 320) ou não marcar fronteira alguma entre o discurso citante e o discurso citado. Trata-se aqui do discurso directo livre, forma que conserva a estrutura deíctica dos elementos linguísticos, a substância e o sentido geral mas sem qualquer sinalização.

No excerto seguinte, o discurso citado não é marcado com sinalização nem introduzido com verbo de fala. Só as marcas deícticas permitem distinguir o discurso 
citante do discurso citado:

o meu pai que expulsou a filha da madrinha da mãe dele para um lar sei lá onde

(- Tem até ao fim do mês para sair de cá)

juntamente com a máquina de costura e o brochezinho que não valia nada, ainda a visitou por uns tempos

(- Boa tarde boa tarde)

e Ihe pagou o quarto antes de se esquecer dela, uma camponesa não é verdade pai, acostumada a amochar da mesma forma que você amochado agora, com receio que a minha mãe ou a minha irmã ou o carneiro mal morto nos oiçam e não ouvem descanse, digo-Ihe isto nos olhos, você escuta-me com os olhos e portanto não ouvem nesta mudez dos feriados no jardim Constantino com tudo deserto em volta $[\ldots]($ p. 206, 207)

No fragmento "uma camponesa não é verdade pai [...] nesta mudez dos feriados no Jardim Constantino" percebe-se que se trata de discurso directo livre, discurso relatado que tem as propriedades linguísticas do discurso directo mas sem nenhum elemento sinalizador. Somente os deícticos servem de índices de que houve citação directa.

As duas vozes que em polifonia se ouvem, no discurso directo ou no discurso directo livre, da responsabilidade de locutores enquanto enunciadores do discurso ou narradores da história, mantêm-se nitidamente distintas e uma voz não é absorvida pela outra, como acontece com o discurso indirecto livre, que, curiosamente, não tem expressividade neste romance. O uso do discurso directo livre dá nota do carácter espontâneo e vivo das vozes ao mesmo tempo que permite introduzir com vivacidade matizes de modalização discursiva como é o caso do fragmento citado em que o tom de reprovação faz lei.

Além destes dois modos de reprodução do discurso (discurso directo e discurso directo livre), também o discurso indirecto conjuncional vai pontuando o romance aqui e além:

Um dia sumiu-se do Jardim Constantino mas à cautela, se me aproximava do banco, falava sempre mais baixo, disseram-me na capelita que uma furgoneta atropelou o carrito, uma das rodas soltou-se e continuou sozinha, muito direita, até ao fim do passeio, eu a interessar-me pelo bebé inventado ( $p .182$ )

As visitas foram-se embora e a tua irmã nem um aceno ali às voltas com o jogo, lembras-te da tua mãe a contar que a malcriada só dobrou o jornal depois das três da manhã, pôs-lhe a caneta em cima, anunciou para ninguém à frente dela salvo os móveis, o piano, as árvores que me bolem com os nervos a repetirem-nos o nome ( $p .189)$

[...] perguntei-Ihe se estava com gripe

- Estás com gripe?

e respondeu-me que não enquanto ia arrancando aos vizinhos, num ódio minucioso, algerozes, varandas, perguntei-Ihe se ia fazer a consulta do hospital e ele calado, mais um 
algeroz, uma varanda, no óculo da máquina de lavar camisas suas às voltas [...] (p. 319)

O discurso indirecto conjuncional é introduzido por um verbo de fala (disseramme, a contar, perguntei-Ihe) e por uma conjunção o que origina um só enunciado com o discurso relatante. Neste discurso específico, não são as palavras que são relatadas mas o conteúdo do pensamento. Desta forma, no discurso indirecto não há senão uma única situação de enunciação na qual o discurso citado perde a sua autonomia enunciativa, tornando-se assim dependente do verbo introdutor.

Em síntese: em Eu Hei-de Amar Uma Pedra, e numa perspectiva interaccionista, os enunciados fónicos apresentam-se como uma súmula de valores estéticos e semântico-pragmáticos mais ou menos evidentes no quadro da narrativa, o que deixa ao leitor a possibilidade de seleccionar o que se the apresenta como mais pertinente para "agarrar" os fios da narrativa (o autor propõe, o leitor dispõe). Em termos metafóricos (inspirados na teoria dos jogos), cada intervenção, seja ela monofónica (discurso narrativizado de primeira pessoa), diafónica (diálogo entre dois interlocutores) ou polifónica (integração de vozes discursivas no discurso do locutor), é como uma pedra jogada que se enfileira em linhas mais ou menos directas, mais ou menos cruzadas de encadeamentos possíveis, mas que não são todos equivalentes no que diz respeito ao seu grau de probabilidade, nem aos seus efeitos e consequências sobre a sequência narrativa. Está reservado ao leitor tentar reconstituir passo a passo os diferentes modos de processamento das interacções discursivas e saber enquadrá-las no desenvolvimento da narrativa, sabendo de antemão que cada acto de fala só faz sentido se integrado na actividade de que faz parte. As palavras não só participam da acção como são também elas próprias acções (Malinowski, 1974).

Diversas tentativas visando a implicação / aplicação da noção de acto de fala ao discurso ficcional emergiram nos anos sessenta nos países anglo-saxónicos. Uns repudiam a ideia de "pragmatização" da obra literária argumentando que o texto de ficção é desprovido de todo o valor de acção; outros, na sequência de Sartre ("L'écrivain est un parleur: il designe, démontre, ordonne, refuse, interpelle, suplie, insulte, persuade", (Sartre, 1972, p. 70) lembram que os textos literários produzem nos seus leitores certos efeitos cognitivos e emocionais (fazem medo, fazem rir, fazem chorar...).

De qualquer modo, o discurso literário como tal pode ser considerado como constituindo uma espécie de meta-género (lembre-se que um dos critérios para a edificação da tipologia dos géneros feita pela tradição retórica se baseava nos valores ilocutórios e nos efeitos perlocutórios) implicando um "pacto ilocutório" e condições de sucesso bem particulares (Maingueneau, 1990). Do ponto de vista da obra, o autor faz dialogar as figuras fictivas entre si por meio de simulacros de gente em conversas que, sendo actos de fala, a literatura tem de dar disso uma imagem fiel.

No caso dos discursos em acto na obra antuniana, os actos de fala constituem um fabuloso tesouro. Oferece-nos não só paradigmas de uma grande multiplicidade de enunciações como possibilita análises diversificadas e profundas que não fi- 
cam a dever nada aos melhores especialistas de análise conversacional. Na obra antuniana o "dizer" é por excelência um "fazer" (quando esse "dizer" contribui eficazmente para fazer progredir a acção romanesca) (Magné, 1972).

A análise dos actos de fala esclarece eficazmente o funcionamento do diálogo romanesco nas obras de António Lobo Antunes ao mesmo tempo que explicita o seu lado dramático, cujas obras não deixam também de o ser: um drama em pessoas. A metáfora teatral de que a personalidade de cada um se tece dos papéis representados através do falar e do ouvir, põe em relevo a importância da influência das vozes discursivas no viver afectivo e cognitivo do ser humano.

Que o diga a sensibilidade do próprio autor: "Como viver sem estas vozes, esta necessidade estranha que desde os sete anos ou oito anos é a minha razão e o meu sentido" ("Crónica com um sorriso no fim", Visão, 04 dez. 2008).

\section{Bibliografia:}

AUSTIN, J. L. Quand dire, c'est faire. Paris: Seuil, 1970.

BAKHTINE, M. Esthétique de la création verbal. Paris: Gallimard, 1984.

FIGUEIREDO, O. Restos de frases, ecos de gente ou a reformulação discursiva em Que Farei Quando Tudo Arde. In: Da Língua ao Discurso. Porto: Campo das Letras: 2004a.

A retoma dos discursos diafônico e polifônico em dois romances portugueses contemporâneos", in Lingu(agem), Macapá: ILAPEC, 2004b.

. Da polifonia irónica à interrogação retórica em Ontem não te vi em BabiIônia. In: O Fascínio da Linguagem, Actas do Colóquio de homenagem a Fernanda Irene Fonseca, Centro de Linguística da Universidade do Porto / Universidade do Porto, 2008.

LOBO ANTUNES, A. O Mecânico, Visão, Lisboa, 5 dez. 2002.

. Eu Hei-de Amar Uma Pedra. Lisboa: Publicações Dom Quixote, 2004.

LOURENÇO, E. A Morte do Pai, Visão, 23 set. 2004.

MAGNÉ, B. L'école des femmes ou la conquête de la parole. Revue des sciences humaines, v. 145, 1972.

MAINGUENEAU, D. Approches de I'énonciation en linguistique française. Paris: Hachette Université, 1981

MALINOWSKI, B. K. Les Jardins de Corail. Paris: Maspéro, 1974.

SARTRE, J. P. Qu'est-ce que la littérature. Genève: Droz, 1972.

\section{Title:}

From the Report of Discourse to the Polyphonic Discourse in Eu Hei-de Amar uma Pedra 


\section{Abstract:}

The novel Eu Hei-de Amar uma Pedra is a characteristic novel within the work of Lobo Antunes. It is a work in which there is not one novelistic line as in traditional novels. The novel is organized into four parts (the photographs; the consultations; the visits; the narratives), apparently without any sense connecting them. But the connecting thread among them lies in the voices of the characters, which are heard throughout the novel in memories of moments of their lives. The polyphonic play of the many voices repeated till exhaustion keeps the characters alive through the ilocutory power of enunciation. Thus, subjectivity is transformed into intersubjectivity and in the mirroring of psychological acts that are expressed through loose units, leaving to the reader the task of fitting one into the other. Thus, the characters acquire body and soul along the work by means of echoing evocations in every speech act, which, though propositionally identical, become intentionally different by each repetition. To say is to do, but to say is also to build oneself. The analysis of the speech acts clarifies efficiently the workings of the novelistic dialogues in the work of António Lobo Antunes. The same happens in this novel.

\section{Keywords:}

Reported discourse; speech acts; polyphony 